\title{
ENVIRONMENTAL ASPECT OF POPULATION ORGANISATION OF TERRESTRIAL MOLLUSK Brephulopsis cylindrica (PULMONATA, BULIMINIDAE) IN SPACE AND TIME AT A REMEDIATION TERRITORY (NIKOPOL MANGANESE ORE BASIN)
}

\author{
KATERYNA KOLESNYKOVA ${ }^{1}$, GALINA ZADOROZHNA $\otimes^{2}$ \\ ${ }^{1}$ Dnipro University of Technology, 49005 Dnipro, av. Dmytra Yavornytskoho, 19, Dnipropetrovsk region, Ukraine \\ ${ }^{2}$ Dnieper-Orilskiy' Nature Reserve, 52030 Obukhovka, Dniprovsk district, Dnipropetrovsk region, Ukraine; e-mail: eandrusevich.311089@gmail.com, za- \\ dorojhnayagalina@gmail.com
}

Corresponding author

Received: 2 March 2021 / Accepted: 27 September 2021

\begin{abstract}
Kolesnykova K., Zadorozhna G.: Environmental aspect of population organisation of terrestrial mollusk Brephulopsis cylindrica (Pulmonata, Buliminidae) in space and time at a remediation territory (Nikopol manganese ore basin). Ekológia (Bratislava), Vol. 40, No. 4, p. 379-383, 2021.

Density variability of a population of the mollusk Brephulopsis cylindrica (Menke, 1828) was studied at a reclaimed site in the Nikopol manganese ore basin. This study was conducted on sod-lithogenic soil on grey-green clay. The samples were collected over 3 years, 3 times a year, on a regular grid. Lexis aggregation index $(\lambda)$ and geostatistical tools were used to characterise spatial distribution of the mollusks. The correlation between the distribution of $B$. cylindrica and environmental factors was established using correlation analysis. Valid correlations were identified between distribution of the mollusk and variation of the fraction content in composition of structural aggregates of soil. Also, valid correlations were identified with plant species composition at the reclaimed site.
\end{abstract}

Key words: mollusk, remediation, geostatistics, composition of structural aggregates, vegetation.

\section{Introduction}

The uneven spatial distribution of organisms has been known for a long time and is one of the most important characteristics of response to environmental factors (Snegin et al., 2017). Spatial ecology of soil animals allows one to solve a wide range of tasks that aim at clarification of structure patterns and functioning of soil biota (Pokarzhevsky et al., 2007). The study of the specifics of spatial organisation of a living organism community allows development of principles of rational and efficient use of natural capital and ways to conserve biodiversity (Arora, 2018).

Mollusks are an important link in nutrient cycling and energy transformation in terrestrial ecosystems as consumers of living and dead parts of plants and fungi. The terrestrial mollusk Brephulopsis cylindrica (Menke, 1828) is a common species of arid landscapes of Crimea and the North-West Black Sea Coast. This species inhabits open biotopes of natural and urban ecosystems (Shilejko, 1984). It is a xerophilic species, and it forms clusters on the steppe sites, often on the blades of grass and shrubs (Gural-Sverlova, Gural, 2012; Kramarenko, Dovgal, 2014). The study of geographical heterogeneity of animal populations is relevant and meaningful because to meet the challenges of monitoring and biodiversity conservation, it is necessary to conduct inventories of communities and to assess their spatial and temporal change.

Environmental factors that affect the distribution of species are generally spatially structured. Consequently, communities also have spatial structure (Dray et al., 2006; Soininen, 2015). Environmental factors affect animals in the form of indivisible combinations of natural and anthropogenic regimes. Technogenic effects on ecosystems are frequently determining in conditions of high human activities. A clear example of the effects of technogenic impacts on ecosystems is land reclaimed after open mining operations (Buta et al., 2019). Young ecosystems that are located on reclaimed land are characterised by a diverse set of regimes and relatively low biodiversity (Andrusevich, Shtirts, 2014; Andrusevych, Zadorozhnaya, 2019). Natural heterogeneity of conditions in such ecosystems is combined with artificially created heterogeneity (Zadorozhnaya, 2018). Identification and monitoring of the relationship between spatial heterogeneity of biota distribution and such regimes are needed to monitor development and remediation of ecosystems (Ravkin, Livanov, 2008).

The aim of this paper is to study the dynamics of density of the terrestrial mollusk B. cylindrica in space and time, in order to

(c) The Author(s) 2021. This is an open access article distributed under the terms of the CC BY-NC-ND license.

https://content.sciendo.com/view/journals/eko/eko-overview.xml 
establish the relationship between distribution of mollusks and spatial heterogeneity of environmental factors on the reclaimed land.

\section{Material and methods}

The research was carried out at a reclaimed site in the Nikopol manganese ore basin for 3 years (city of Pokrov). The experimental site is located on sod-lithogenic soil on grey-green clay. Mining activity ceased 40 years ago. The soil has been named according to Yeterevska et al. (2008). According to IUSS Working Group WRB (2015), the soil is called Hyperskeletic Technosol (Calcic, Supramollic, Vertic).

The test site was a regular grid of seven transects with 15 sampling points in each. The distance between the sampling points was $3 \mathrm{~m}$. Accordingly, the dimensions of the test site were $18 \times 42 \mathrm{~m}$.

Samples of mollusks were collected in 2012, 2013 and 2014 each season (in May, June, October) from each point of the test site. In total, 945 samplings (9.660 specimens) were collected. Collection of mollusk shells was done manually. The size of each sampling point was $50 \times 50 \mathrm{~cm}$.

Vegetation (species composition and projective cover of each species) was described for each point of the test site. The total projective plant cover was taken as the sum of projective cover of all species.

Soil heterogeneity was assessed by measuring the variation of fraction content in the composition of structural aggregates of the soil. Samples for determining the fraction content in the composition of structural aggregates were collected in 2012. The method of dry screening by Savinov (Zhukov et al., 2013; Blaud et al., 2017) was used. A sieve with holes of diameter 10, 7, 5, 3, $1,0.5$ and $0.25 \mathrm{~mm}$ was used.

Assessment of average indicators (x), standard error (SE), coefficient of variation $(\mathrm{CV})$ and standard deviation $(\sigma)$ was performed using descriptive statistics.

The type of the spatial distribution of specimens of mollusks was established using Lexis aggregation index (Giljarov, 1983; Chernov, 2008):

$$
\lambda=\frac{\sigma}{\sqrt{\chi}}
$$

Table 1. Population density statistics of mollusks Brephulopsis cylindrica.

\begin{tabular}{|l|c|c|c|c|}
\hline Sampling time & $\boldsymbol{x} \pm \mathbf{S E}\left(\mathbf{n} / \mathbf{m}^{\mathbf{2}}\right)$ & $\mathbf{C V}(\boldsymbol{\%})$ & $\boldsymbol{\sigma}$ & $\boldsymbol{\lambda}$ \\
\hline May_2012 & $79.20 \pm 5.40$ & 69.87 & 55.34 & 6.22 \\
\hline June_2012 & $68.99 \pm 5.23$ & 77.67 & 53.58 & 6.45 \\
\hline October_2012 & $26.82 \pm 1.69$ & 64.51 & 17.30 & 3.34 \\
\hline May_2013 & $33.30 \pm 1.92$ & 59.01 & 19.65 & 3.41 \\
\hline June_2013 & $33.45 \pm 2.20$ & 67.55 & 22.59 & 3.91 \\
\hline October_2013 & $49.87 \pm 3.71$ & 76.24 & 38.02 & 5.38 \\
\hline May_2014 & $10.97 \pm 0.97$ & 90.87 & 9.97 & 3.01 \\
\hline June_2014 & $23.12 \pm 1.44$ & 63.83 & 14.76 & 3.07 \\
\hline October_2014 & $42.70 \pm 2.90$ & 69.70 & 29.77 & 4.56 \\
\hline
\end{tabular}

Notes: $x$ - mean; SE - standard error; CV - coefficient of variation; $\sigma$ - standard deviation; $\lambda$ - coefficient of aggregation coefficient. where $\lambda$ is the aggregation coefficient, $\sigma$ the standard deviation and $x$ is the average value.

Geostatistical analysis of data was used to determine the level of spatial dependence of density of $B$. cylindrica (Veronese Jr. et al., 2006; Webster, Oliver, 2007; Valbuena Calderon et al., 2008).

Spatial dependence level (SDL) was calculated based on the formula:

$$
S D L=\frac{C_{0}}{C_{0}+C_{1}} \times 100
$$

where $\mathrm{C}_{0}$ is the nugget effect and $\mathrm{C}_{1}$ is the partial threshold.

The rate of $\mathrm{C}_{0}, \mathrm{C}_{1}$ and range radius $(\mathrm{R})$ were obtained from modelling of a variogram of spatial variability of aggregations of mollusks B. cylindrica (Legendre, Legendre, 1998; Webster, Oliver, 2007).

Correlation analysis was used to establish a link between distribution of specimens of mollusks and external factors of environment.

\section{Results and discussion}

The average density of $B$. cylindrica considerably changed in the different years and seasons of the study (Table 1).

The high-density indicators for spring and summer of 2012 decreased by more than 2.5 times in comparison to autumn. On the contrary, in 2013 , the density increased by 1.5 times over the season. In 2014, the population density of B. cylindrica gradually increased by more than 4 times from the lowest values between May and October.The variability of the mollusk population density was quite high. In 2012, the CV averaged 70.68\%, in 2013 $-67.60 \%$ and in $2014-74.80 \%$.

The aggregation coefficient $(\lambda)$ is used to assess the nature of distribution of the species over the territory. An aggregated distribution of individuals corresponds to an index value greater than 1 , a random one - an index close to 1 and a uniform distribution of individuals over an area - an index close to 0 (Giljarov et al., 1979). According to the data obtained, the distribution of individuals over the studied polygon can be characterised as aggregated. Aggregation index values significantly exceeded unity in all cases (Table 1 ).

Table 2. Geostatistical parameters of Brephulopsis cylindrica distribution.

\begin{tabular}{|lcccc|}
\hline Sample collection time & $\mathbf{C}_{\mathbf{0}}$ & $\mathbf{C}_{\mathbf{1}}$ & SDL (\%) & R (M) \\
\hline May_2012 & 492 & 2011 & 19.66 & 13.2 \\
\hline June_2012 & 741 & 1821 & 28.93 & 5.3 \\
\hline October_2012 & 62 & 199 & 23.73 & 7.6 \\
\hline May_2013 & 75 & 234 & 24.19 & 4.9 \\
\hline June_2013 & 104 & 155 & 40.18 & 6.0 \\
\hline October_2013 & 45 & 1218 & 3.56 & 4.4 \\
\hline May_2014 & 32 & 53 & 37.61 & 5.8 \\
\hline June_2014 & 100 & 87 & 53.56 & 6.2 \\
\hline October_2014 & 204 & 315 & 39.31 & 6.4 \\
\hline
\end{tabular}

Notes: $C_{0}$ - nugget; $C_{1}$ - partial threshold; $\mathrm{SDL}$ - spatial dependence level $(100 \times \mathrm{C} 0 /(\mathrm{C} 0+\mathrm{C} 1)) ; R$ - radius of influence. 

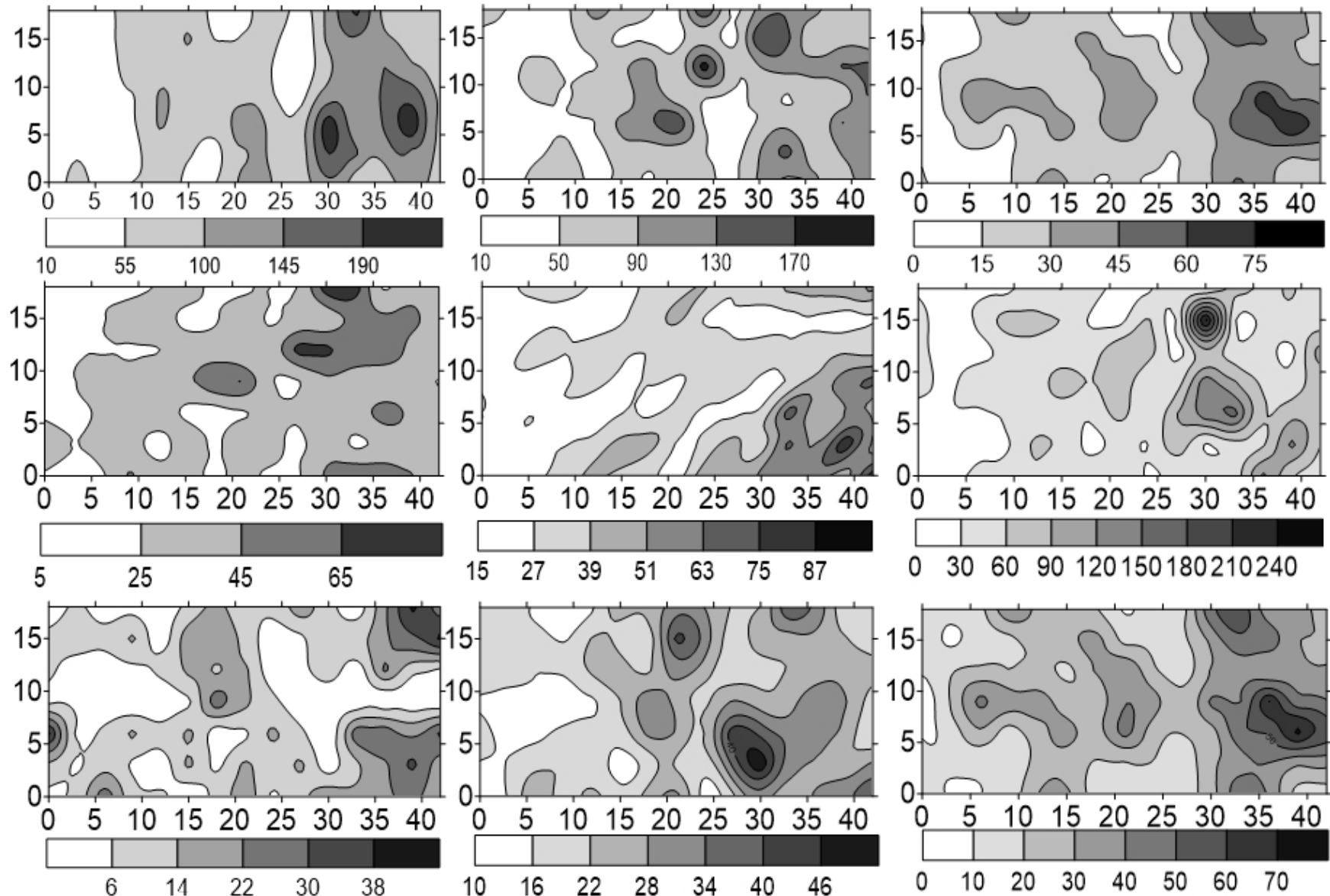

Fig. 1. Maps of the spatial distribution of the mollusk Brephulopsis cylindrica in 2012, 2013 and 2014 (by seasons in sod-lithogenic soils on grey-green clay).

The geostatistical approach greatly expands the capabilities of data description. Geostatistics offers a number of mechanisms that take into account the spatial distribution laws of the obtained data, describing spatial models, and helps to interpolate the value for places where measurements were not taken ( $\mathrm{Za}$ dorozhna, 2018).

The nugget effect indicates the significance of the nonspatial component of the variability of the feature and reflects the heterogeneity of the feature, which is less than the variogram calculation step. Taking into account the partial threshold (spatial component of variability) and the nugget effect together makes it possible to assess the level of spatial dependence (SDL score, or spatial relationship). This indicator ranges from 0 to $100 \%$.

If the spatial relation is in the range of $0-25 \%$, then we are talking about a strong spatial dependence; if the spatial relationship is in the range of $25-75 \%$, then the spatial dependence of the variable is moderate; when the spatial ratio exceeds $75 \%$, the variable is regarded as weakly spatially dependent (Faechner et al., 2000).

In our study, the SDL values for spring and autumn of 2012 and 2013 were $<25 \%$, which indicates a high spatial dependence of the data (Table 2). In the data of summer sampling for 2012 and 2013, the spatial relation was in the range $25-75 \%$ and the spatial dependence of the variable was moderate. The 2014 data indicate an average level of spatial dependence of the mollusk distribution.

The radius of influence indicates the distance beyond which the variogram reaches a plateau. This is the distance within which there is a relationship between points in space according to the studied attribute (Zadorozhnaya, 2018). This feature is related to the size of aggregations that can be found when studying the spatial distribution maps of B. cylindrica (Fig. 1). According to the results of our study, the size of the radius of influence of the data on the distribution of the mollusk ranges from 4.4 to $13.2 \mathrm{~m}$ (Table 2).

On the presented maps of the spatial variability of the population density of B. cylindrica, areas with a higher density of individuals are marked with a dark colour and areas with a lower density with a light colour. The configurations of areas with a higher density of mollusks change over time. That is, the location of the mollusk concentrations is changing, but this is of an aggregated nature, which confirms the results of calculating the Lexis aggregation coefficient.

The change in the density of the species under study is consistent with the heterogeneity of the external conditions. The study of the vegetation cover of the experimental site showed that 29,36 and 32 plant species grew on the experimental site in 2012, 2013 and 2014, respectively. The dominant species in the 
Table 3. Results of correlation analysis of data on density of Brephulopsis cylindrica and aggregate composition of soil $(p \leq 0.05)$.

\begin{tabular}{|c|c|c|c|c|c|c|c|c|c|}
\hline \multirow{3}{*}{$\mathrm{D}, \mathbf{m m}$} & \multicolumn{9}{|c|}{ Sample collection time } \\
\hline & \multicolumn{3}{|c|}{2012} & \multicolumn{3}{|c|}{2013} & \multicolumn{3}{|c|}{2014} \\
\hline & May & June & October & May & June & October & May & June & October \\
\hline$>10$ & -0.19 & -0.18 & $-0.24^{*}$ & -0.09 & -0.06 & -0.13 & -0.05 & -0.07 & -0.17 \\
\hline $7-10$ & -0.08 & -0.10 & -0.17 & 0.13 & -0.07 & -0.01 & 0.03 & -0.02 & 0.10 \\
\hline $5-7$ & -0.03 & 0.09 & -0.08 & 0.03 & -0.04 & 0.03 & 0.18 & -0.08 & 0.11 \\
\hline $3-5$ & 0.16 & 0.08 & 0.09 & 0.14 & $0.23^{\star}$ & 0.15 & $0.38^{*}$ & 0.09 & $0.22^{\star}$ \\
\hline $1-3$ & 0.15 & 0.08 & $0.22^{*}$ & -0.06 & 0.05 & 0.02 & -0.15 & 0.04 & -0.03 \\
\hline $0.5-1$ & -0.10 & 0.01 & -0.04 & -0.03 & $-0.25^{*}$ & -0.08 & -0.14 & -0.02 & -0.11 \\
\hline $0.25-0.5$ & -0.15 & -0.03 & -0.07 & -0.08 & -0.18 & -0.08 & $-0.24^{*}$ & -0.03 & -0.15 \\
\hline$<0.25$ & $-0.22^{*}$ & -0.04 & -0.06 & 0.00 & -0.13 & -0.06 & $-0.29^{*}$ & -0.06 & -0.07 \\
\hline
\end{tabular}

Note: ${ }^{\star}$ There are cases of significant correlations.

community were Bromus squarrosus L., Medicago sativa L., Seseli tortuosum L. and Achillea micrantha Willd. The total projective plant cover at the sampling points ranged from 2 to $93 \%$. Correlation analysis showed that the distribution of B. cylindrica reliably depends on the projective cover of some plant species ( $p \leq$ $0.05)$. Both positive and negative correlations were revealed. Positive correlation was observed with the distribution of Centaurea scabosa L., Lotus ucrainicus Klkov, Medicago sativa, M. romanica Prod., Tragopogon major Jacq., Artemisia absinthium L., Achillea millefolium L., Chondrilla juncea L., Taraxacum officinale Wigg., Silene dichotoma Ehrh. and Senecio vernalis Waldst. et Kit.

The distribution of the mollusk negatively correlated with abundance of the following plant species: Melilotus albus Medik., Erysimum diffusum Ehrh., Lactuca tatarica (L.) C.A.Mey, Onobrychis viciifolia Scop. and Anthemis arvensis L. There was no significant correlation with the total projective cover of plants.

The heterogeneity of the soil also affected the distribution of the mollusk. It was found that Brephulopsis cylindrica reacted to the aggregate composition of the soil (Table 3 ).

Significant positive correlations were found between the distribution of agronomically valuable fractions with a diameter of 3-5 and 1-3 mm. A significant negative relationship was observed with a lumpy aggregate fraction $(>10 \mathrm{~mm})$ and fine fractions with an aggregate diameter $<1 \mathrm{~mm}$.

Our study showed that $B$. cylindrica mollusks in reclaimed soil formed concentrations in some areas and were uncommon in others. These clusters had an organised character and had their own structure, which was found using statistical tools. The structure of the mollusk population was associated with the variability of environmental conditions.

The capacity for concentration is a biological characteristic of a species. Spatial differentiation of a species is the first stage in the formation of each population as the main unit of the evolutionary process. It is the basis on which differentiation arises according to other biological indicators including genetic heterogeneity as a whole. The uniformity of the species distribution is observed against the background of relatively uniform external conditions when the competition of individuals for resources is decisive. In this case, these influences play a subordinate role. The decisive factor is the along-surface heterogeneity of ecosystem components, primarily soil (García-Palacios et al., 2011, 2012; Štursová et al., 2016).
Spatial heterogeneity is the most important property of the soil, which manifests itself at various scale levels of organisation of the pedosphere (Medvedev, 2010; Zhang et al., 2014; Zuo et al., 2009; Yavitt, 2009). The initial heterogeneity of the reclaimed land and the complex nature of the dynamics of the soil-forming process led to a high diversity of environmental conditions at the reclamation site (Zadorozhnaya et al., 2018). The formation of a mosaic soil cover arose as a result of the peculiarities of laying the experimental site at the technical stage of reclamation and long-term agricultural reclamation of the disturbed lands. The existence of reliable correlations between the indicators of soil heterogeneity in 2012 and the distribution of the mollusk in 2013 and 2014 indicates an external influence on the distribution of the species. This relationship is realised through vegetation.

It is known that the aggregate composition of the soil has a significant effect on the life of plants (Czachor et al., 2015). The heterogeneity of soil conditions leads to spatial and temporal variability in the growth of species and formation of the configuration of the entire plant community (Farjalla et al., 2012). Such heterogeneity is much more pronounced under conditions of reclamation than in natural ecosystems (Andrusevich, Shtirts, 2014; Andrusevych, Zadorozhnaya, 2019). However, this influence is not simply a consequence of the abundance of vegetation. There is no correlation between the B. cylindrica density and the total projective cover. The mollusk reacts to specific types of plants, prefers some types of plants and avoids others. Its uneven presence as a consumer of living and dead parts of various plants and fungi becomes an ecological factor of the ecosystem. The latter enhances the heterogeneity of the conditions of the artificial ecosystem. Thus, the complex spatial structure of environmental factors imposes adjustments on the population structure originally inherent in the species and forms the spatial structure of the community, which contributes to an increase in biodiversity.

\section{Conclusion}

The average density of $B$. cylindrica on the reclamation site varied significantly in space and time. The CV of the data collected at one time reached $91 \%$. The population density during 1 year of the study changed by 1.5-4 times.

The distribution of individuals over the studied polygon was aggregated. The Lexis aggregation index was 3.01-6.45. The spa- 
tial relationship of the SDL indicated a high to medium level of spatial dependence of the data. The influence radius of the $B$. $c y$ lindrica distribution data varied within the range of 4.4-13.2 m.

The distribution density of B. cylindrica depended on the species composition of the vegetation. Positive correlation was observed with the distribution of Centaurea scabosa, Lotus ucrainicus, Medicago sativa, M. romanica, Tragopogon major, Artemisia absinthium, Achillea millefolium, Chondrilla juncea, Taraxacum officinale, Silene dichotoma and Senecio vernalis. The distribution of the mollusk negatively correlated with the abundance of plant species such as Melilotus albus, Erysimum diffusum, Lactuca tatarica, Onobrychis viciifolia and Anthemis arvensis.

The distribution density of Brephulopsis cylindrica depends on the heterogeneity of the soil in terms of its aggregate composition. Significant positive correlations were found between the distribution of fractions with a diameter of 3-5 and 1-3 $\mathrm{mm}$. A significant negative dependence was observed with an aggregate fraction with a diameter of $>10 \mathrm{~mm}$ and fractions with an aggregate diameter of $<1 \mathrm{~mm}$.

\section{References}

Andrusevich, E.V. \& Shtirts Yu.A. (2014). Ekologicheskoe raznoobrazie rastitelnogo pokrova tehnozemov uchastka rekultivatsii Nikopolskogo margantsevorudnogo basseyna. Industrial Botany, 14, 115-127.

Andrusevych, K. \& Zadorozhnaya G. (2019). Diversity, dynamics and ecological analysis of flora of reclaimed soil. Folia Oecologica, 46(2), 153-163. DOI:10.2478/foecol-2019-0018.

Arora, N.K. (2018). Biodiversity conservation for sustainable future Environmental Sustainability, 1, 109-111. DOI: 10.1007/s42398-0180023-1.

Blaud, A., Menon, M., van der Zaan, B., Lair, G.J. \& Banwar S.A. (2017) Chapter five - Effects of dry and wet sieving of soil on identification and interpretation of microbial community composition. Adv. Agr., 142 119-142. DOI: 10.1016/bs.agron.2016.10.006.

Buta, M., Blaga, G., Paulette, L., Păcurar, I., Roşca, S., Borsai, O., Grecu, F., Sînziana, P. \& Negruşier C. (2019). Soil reclamation of abandoned mine lands by revegetation in northwestern part of Transylvania: a 40year retrospective study. Sustainability, 11(12), 3393. DOI: 10.3390/ su11123393.

Chernov, Ju.I. (2008). Jekologija i biogeografija. Moscow: Tovarishhestvo nauchnyh izdanij KMK.

Czachor, H., Charytanowicz, M., Gonet, S., Niewczas, J., Jozefaciuk, G. \& Lichner L. (2015). Impact of long-term mineral and organic fertilizer application on the water stability, wettability and porosity of aggregates obtained from two loamy soils. Eur. J. Soil Sci., 66(3), 577. DOI: 10.1111/ejss.12242.

Dray, S., Legendre, P. \& Peres-Neto P. (2006). Spatial modelling: a com prehensive framework for principal coordinate analysis of neighbours matrices (PCNM). Ecol. Model., 196, 483-493. DOI: 10.1016/j. ecolmodel.2006.02.015

Faechner, T., Pyrcz, M.J. \& Deutsch C.V. (2000). Soil remediation decision making in presence of uncertainty in crop yield response. Geoderma, 97, 21-38. DOI: 10.1016/S0016-7061(00)00024-0.

Farjalla, V.F., Srivastava, D.S., Marino, N.A.C., Azevedo, F.D., Dib, V., Lopes, P.M., Rosado, A.S., Bazelli, R.L. \& Esteves F.A. (2012). Ecological determinism increases with organism size. Ecology, 93(7), 1752-1759. DOI: 10.1890/11-1144.1.

García-Palacios, P., Maestre, F.T., Bardgett, R.D. \& de Kroon H. (2012). Plant responses to soil heterogeneity and global environmental change. J. Ecol., 100(6), 1303-1314. DOI: 10.1111/j.1365-2745.2012.02014.x.

García-Palacios, P., Maestre, F.T. \& Gallardo A. (2011). Soil nutrient heterogeneity modulates ecosystem responses to changes in the identity and richness of plant functional groups. J. Ecol., 99(2), 551-562. DOI: 10.1111/j.1365-2745.2010.01765.x.

Giljarov, A.M., Chekryzheva, T.A. \& Sadchikov A.P. (1979). Struktura gorizontal'nogo raspredelenija planktona. Hydrobiological Journal, 15(4), $10-18$.
Giljarov, M.S. (1983). Fauna i jekologija pochvennyh bespozvonochnyh Moskovskoj oblasti. Moscow: Nauka.

Gural-Sverlova, N.V. \& Gural R.I. (2012). Naukovi kolekcii Derzhavnogo prirodoznavchogo muzeju. Malakologichnij fond. L'viv.

IUSS Working Group WRB (2015). World reference base for soil resources 2014, update 2015: international soil classification system for naming soils and creating legends for soil maps. World Soil Resources Reports, No. 106. Rome: FAO.

Jacobson, B., Grant, J.W.A. \& Peres-Neto P.R. (2015). The interaction between the spatial distribution of resource patches and population density: consequences for intraspecific growth and morphology. J. Anim. Ecol., 84, 934-942. DOI: 10.1111/1365-2656.12365.

Kramarenko, S.S. \& Dovgal I.V. (2014). Spatial variation of the land snail Brephulopsis cylindrical (Gastropoda, Pulmonata, Enidae): a fractal approach. Vestn. Zool., 48(5), 433-440. DOI: 10.2478/vzoo-2014-0051.

Legendre, P. \& Legendre L. (1998). Numerical ecology. Amsterdam: Elsevier.

Medvedev, V.V. (2010). Neodnorodnost kak zakonomernoe proyavlenie gorizontalnoy strukturyi pochvennogo pokrova. Gruntoznavstvo, 11(1-2), 6-15.

Pokarzhevsky, A.D., Gongalsky, K.B. \& Zaitsev A.S. (2007). Prostranstvennaja jekologija pochvennyh zhivotnyh. Moscow: Galleja Print.

Ravkin, Yu.S. \& Livanov S.G. (2008). Faktornaja zoogeografija. Principy, metody i teoreticheskie predstavlenija. Novosibirsk: Nauka.

Shilejko, A. A. (1984). Nazemnye molljuski podotrjada Pupillina fauny SSSR (Gastropoda, Pulmonata, Geophila). Leningrad: Nauka.

Snegin, E.A., Adamova, V.V. \& Sichev A.A. (2017). Morfo-geneticheskaja izmenchivost' nativnyh i adventivnyh populjacij molljuska Brephulopsis cylindrica (Gastropoda, Pulmonata, Enidae). Ruthenica, 27(3), 119-132. DOI: $10.35885 /$ ruthenica.2017.27(3).3.

Soininen, J. (2015). Spatial structure in ecological communities - a quantitative analysis. Oikos, 125(2), 160-166. DOI: 10.1111/oik.02241.

Štursová, M., Bárta, J., Šantrůčková, H. \& Baldrian P. (2016). Small-scale spatial heterogeneity of ecosystem properties, microbial community composition and microbial activities in a temperate mountain forest soil. FEMS Microbiol. Ecol., 92(12), 185. DOI: 10.1093/femsec/fiw185.

Valbuena Calderon, C.A., Martines, L.J. \& Giraldo H. (2008). Variabilidad espacial del suelo y su relacion con el rendimiento de mango (Mangifera indica L.). Revista Brasileira de Fruticultura, 30(4), 1146-1151. DOI: 10.1590/S0100-29452008000400049.

Verones Junior, V., Carvalho, M.P., Dafonte, J., Freddi, O.S., Vidal Vazquey, E. \& Ingaramo O.E. (2006). Spatial variability of soil water content and mechanical resistance of Brazilian ferralsol. Soil Tillage Res., 85(1-2), 166-177. DOI: 10.1016/j.still.2005.01.018.

Webster, R. \& Oliver M.A. (2007). Geostatistics for environmental scientist. Chichester: John Wiley \& Sons.

Yavitt, J.B., Harms, K.E., Garcia, M., Smithsonian, W., Joseph, S., He, F. \& Mirabello M.J. (2009).Spatial heterogeneity of soil chemical properties in a lowland tropical moist forest, Panama. Austr. J. Soil Res., 47(7), 674-687. DOI: $10.1071 /$ SR08258.

Yeterevska, L.V., Stammerer, G.F. \& Kanash A.P. (2008). Rekultyvovani grunty pidkhody do klasyfikatsii i systematyky. Gruntiznavstvo, 9(3-4) 147-150.

Zadorozhnaya, G. (2018). Spatiotemporal dynamics of soil penetration resistance of recultivated soil. Ekológia (Bratislava), 37(3), 82-89. DOI: 10.2478/eko-2018-0008.

Zadorozhnaya, G.A., Andrusevych, K.V. \& Zhukov O.V. (2018). Soil heterogeneity after recultivation: ecological aspect. Folia Oecologica, 45(1), 46-52. DOI: 10.2478/foecol-2018-0005.

Zhang, Z., Hu, B. \& Hu G. (2014). Spatial heterogeneity of soil chemical properties in a subtropical Karst forest, Southwest China. The Scientific World Journal, 2014(1-2), 473651. DOI: 10.1155/2014/473651.

Zhukov, A.V., Zadorojhna, G.O. \& Lyadskaya I.V. (2013). Agregatnaja struktura tehnozemov Nikopol'skogo margancevo-rudnogo bassejna. Biological Bulletin of Bogdan Chmelnitskiy Melitopol State Pedagogical University, 3(3), 274-286.

Zuo, X., Zhao, X., Zhao, H., Hui, Z. T., Guo, Y., Li, Y. \& Huang Y. (2009). Spatial heterogeneity of soil properties and vegetation-soil relationships following vegetation restoration of mobile dunes in Horqin Sandy Land, Northern China. Plant and Soil, 318(1), 153-167. DOI: 10.1007/s11104008-9826-7. 